\title{
Leucineaminopeptidase in
}

\section{rheumatoid arthritis}

\section{Localization in subchondral bone and in synovial fluid cells}

\author{
UNTO VAINIO \\ From the Third Department of Medicine, University of Helsinki, Finland
}

The histopathological changes caused by rheumatoid arthritis have been known for many years. Typical phenomena include the proliferation of synovial tissue and the inflamatory reactions encountered in it, the increased amount of synovial fluid, and the erosive changes in cartilage and subchondral bone. However, the biochemical reactions leading to erosion have not yet been clarified.

It is thought that the enzymes possibly secreted by pannus are responsible for the erosion of articular cartilage (Lever and Ford, 1958). It is not known by what means pannus might cause cartilage destruction. Homogenates of synovial membrane of a patient suffering from rheumatoid arthritis, in contrast to those of normal synovial membrane, are able to destroy the protein-polysaccharides of cartilage (Ziff, Gribetz, and Lospalluto, 1960). These cited authors suggested that the factor causing decomposition of protein polysaccharide was an endopeptidase.

A similar effect on cartilage protein-polysaccharide was shown by Weissman and Thomas (1963) to reside also in the lysosomal fraction of leucocytes, and by Weissmann and Spilberg (1968) in the lysosomal fraction of hepatic cells. These authors found two factors, one hyaluronidase-like and the other protease-like, which could account for cartilage breakdown. Ali (1964) showed that human cartilage tissue contained a proteolytic enzyme capable of causing autolytic degradation of cartilage.

In rheumatoid synovial fluid, increased acid phosphatase activity has been associated with the activation of lysosomal enzymes in the synovial tissue (Smith and Hamerman, 1962). Aminopeptidase activity correlates well with the degree of joint disease (Ziff, Simson, Scull, Smith, Shatton, and Mainland, 1955). The activity of the same enzyme decreases if, in the rheumatic process, inflammation abates either as a result of successful therapy or spontaneously (Hüttl and Marcović, 1966).

In rheumatoid arthritis about 70 per cent. of the synovial fluid cells are polymorphs, and the rest are mainly mononuclear and exfoliated cells. 'RA cells' described by Hollander and his team (Hollander,
McCarty, Astorga, and Castro-Murillo, 1965; Rawson, Abelson, and Hollander, 1965; Restifo, Lussier, Rawson, Rockey, and Hollander, 1965) display cytoplasmic inclusions containing rheumatoid factor, which they related to the potential rheumatoid factor-phagocytosing property of such cells.

Leucineaminopeptidase (LAP), or naphthylamidase, is an endopeptidase belonging to the group of cathepsins and capable of hydrolysing peptides having a free alpha-amino group on a terminal leucine amino acid. The activity of LAP is altered in certain pathological states. Increased activity has also been reported in many malignant tumours and particularly at points where the tumour shows invasive growth (Burstone, 1956; Glenner, Burstone, and Meyer, 1959).

In normal bone, LAP activity occurs in both osteoblasts and osteoclasts. Resting osteocytes reveal very little or no LAP activity (Lipp, 1959) but, if the resorption of bone is stimulated with dihydrotachysterol (AT 10), the activity of LAP increases strongly at points where the reconstruction of bone by corresponding cells is seen.

In rheumatoid arthritis, increased LAP activity is encountered in subcutaneous nodules (Burstone, 1962) and in hyperplastic synovial tissue (Vainio, 1966). This LAP activity is demonstrable in the lining cells of synovial tissue, in cartilage erosions, in pannus, and around affected blood vessels. The pathological changes of rheumatoid arthritis are easily outlined with the aid of LAP. Since increased LAP activity has been demonstrate in the soft tissues in most manifestations of rheumatoid arthritis, the question arises whether this increased LAP activity also occurs in subchondral bone and synovial fluid cells in this condition. The present study was undertaken in order to clarify this point.

\section{Material and methods}

All pathological samples were derived from patients fulfilling the A.R.A. criteria for definite rheumatoid arthritis (Ropes, Bennett, Cobb, Jacox, and Jessar, 1959), 
including typical histopathological changes in the synovial tissue. The tissue samples were all obtained in the operating theatre from fifteen patients who had been admitted to the Rheumatism Foundation Hospital at Heinola. The samples were taken from the metetarsal capitulum, except one from a knee joint.

Four control specimens were obtained from patients who had died suddenly of myocardial infarction, autopsy being performed within 48 hours of death.

Bone samples measuring $0.5 \times 0.5 \times 0.5 \mathrm{~cm}$. were decalcified with 10 per cent. versene at $+4^{\circ} \mathrm{C}$. according to the method of Balogh $(1962,1963)$ for $24 \mathrm{hrs}$. They were subsequently frozen with dry ice and sectioned by cryostat microtome at 10 to $20 \mu \mathrm{m}$.

Synovial fluid was derived by puncture from ten rheumatoid knee effusions without the use of local anaesthesia. Immediately after puncture, ten smear preparations were made of each synovial fluid and allowed to dry for 20 to $30 \mathrm{~min}$. at room temperature. Some of the preparations were made from the deposit after centrifugation. The slides were preserved at $+4^{\circ} \mathrm{C}$. up to the time of histochemical examination, which followed 2 to 3 hrs later.

LAP was demonstrated histochemically by the method of Nachlas, Crawford, and Seligman (1957), using L-leucyl- $\beta$-naphthylamide as substrate and Fast Blue B as coupling agent. The incubation time was $15 \mathrm{~min}$. for rheumatoid subchondral bone samples, $20 \mathrm{~min}$. for synovial fluid cell samples and 25 to $30 \mathrm{~min}$. for control bone samples.

\section{Results}

Cryostat sections of synovial tissue stained with haematoxylin and eosin were examined for the presence of typical rheumatoid changes in the synovial tissue of joints from which a subchondral bone sample had been taken (Fig. 1). Serial sections were also processed for LAP identification. It was also observed in the present study that pathological changes in rheumatoid arthritis were better visualized with the aid of LAP than by conventional histological methods (Fig. 2).

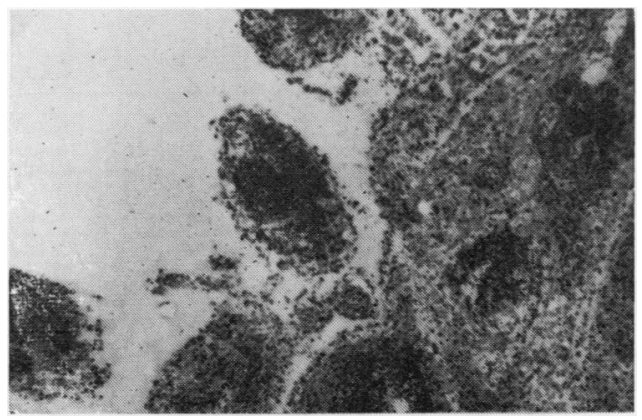

FIG. 1 Rheumatoid arthritis. Typical pathological changes in synovial tissue. Haematoxylin and eosin. $\times 27$.

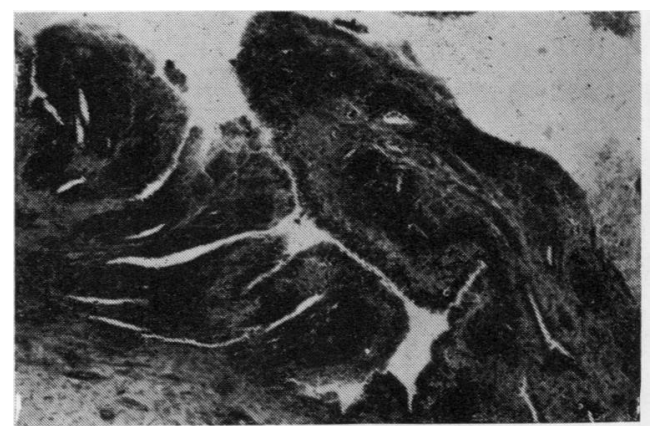

FIG. 2 Rheumatoid arthritis. Villous synovitis, LAP technique. $\times 27$.

In the subchondral bone of rheumatoid arthritis patients, round cell infiltrations was noted, constituting one sign of rheumatoid process (Fig. 3).

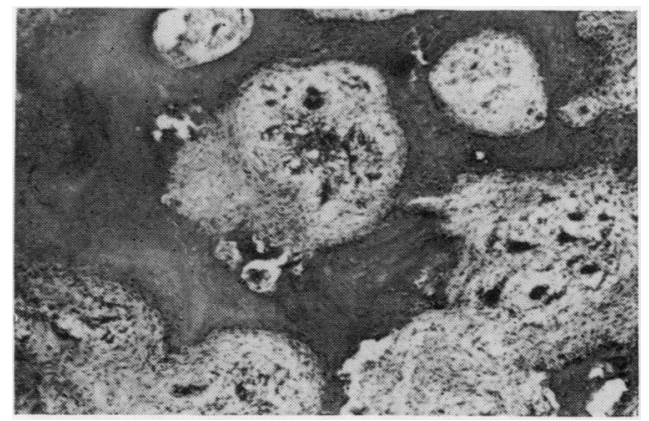

FIG. 3 Rheumatoid arthritis. Subchondral bone with round cell infiltrations. Haematoxylin and eosni. $\times 27$.

LAP activity was noted in all pathological preparations, either in the subchondral bone or in chondrocytes. The intensity of the reaction was sufficient for localization within a $15 \mathrm{~min}$. incubation period; no longer incubation times were required. In the areas of subchondral bone which had undergone pathological change, distinct LAP activity was present (Fig. 4). Enzymatic activity was strongest on the margins of bone trabeculae.

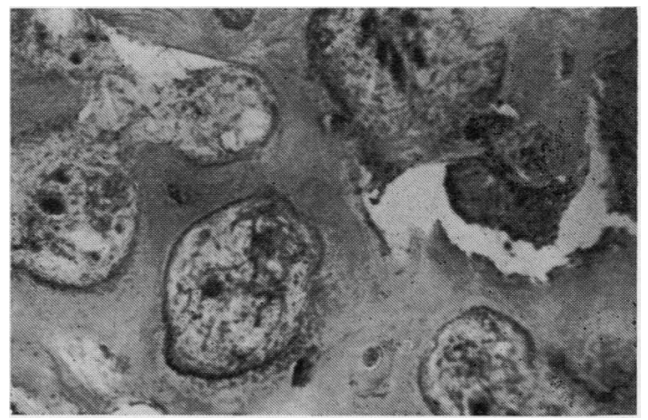

FIG. 4 Rheumatoid arthritis, subchondral bone. Granulation tissue between bone trabeculae. Strongest enzyme reaction at the boundary between bone and granulation tissue. LAP. $\times 27$. 
In the zone between bone and cartilage, enzyme activity was seen in the form of small reaction-foci (Fig. 5), where the serial sections revealed round cell infiltration and fibrinoid necrosis.

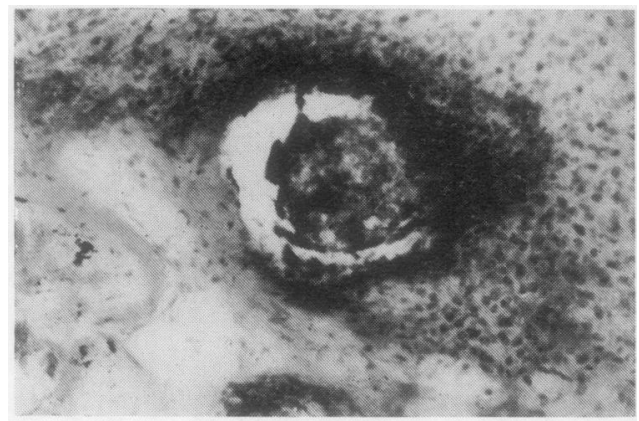

FIG. 5 Rheumatoid arthritis. Focus with strong LAP activity at boundary between bone and articular cartilage. $\times 64$.

In some of the bone trabeculae, small cavities were found in which obvious reabsorption of bone was taking place. In these, too, increased LAP activity was seen, and it was strongest at the edges of microcavities (Fig. 6).

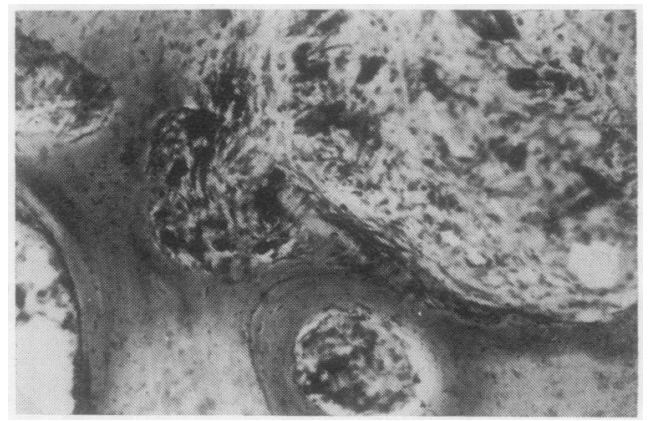

FIG. 6 Rheumatoid arthritis, subchondral bone. LAP activity in erosion of bone trabeculae, strongest activity noted in microcavity, particularly at its margin. LAP. $\times 75$.

In seven out of ten patients, demonstrable LAP activity occurred in synovial fluid cells. This enzyme activity was present in the form of small intracytoplasmic bodies (Figs 7 and 8). Three patients with clinically definite, sero-positive rheumatoid arthritis presented with no LAP activity demonstrable in their synovial fluid cells.

In normal control specimens from subchondral bone, no LAP activity could be seen after $15 \mathrm{~min}$. incubation. After incubation periods of $30 \mathrm{~min}$., slight activity was demonstrable on the margins of some bone trabeculae and in chondrocytes (Fig. 9). Even though incubation times had been doubled, the enzyme activity was still clearly less than that at corresponding points in pathological preparations.

\section{Discussion}

Increased LAP activity occurs at points where histological manifestations of rheumatoid arthritis

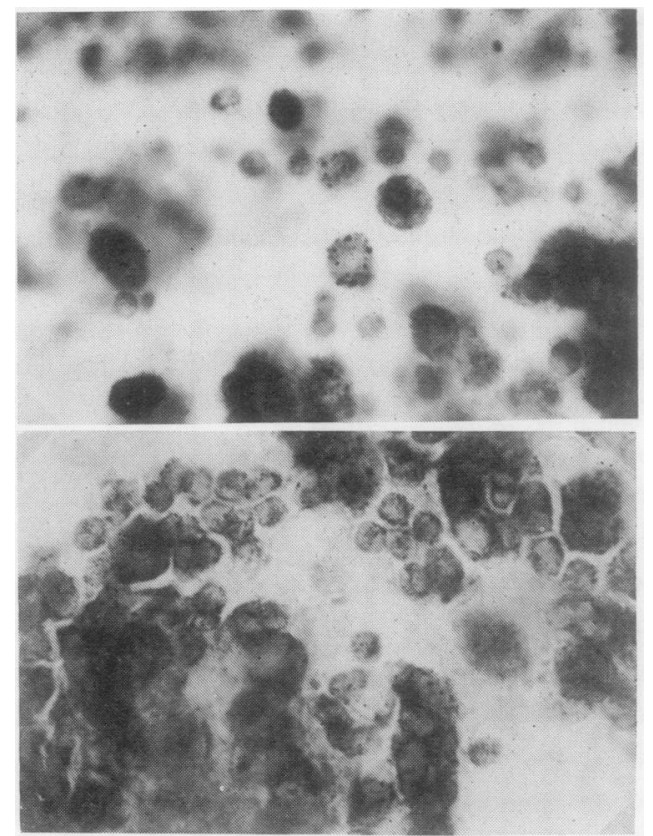

FIGS 7 AND 8 Rheumatoid arthritis. LAP activity in synovial fluid cells. LAP activity present in the form of small intracytoplasmic bodies, resembling those in ' $R$. $A$. cells'. $\times 625$.

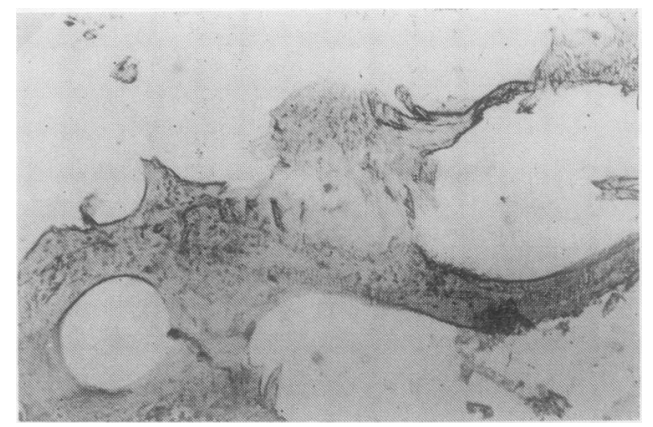

FIG. 9 Normal control, subchondral bone. Slight LAP activity at margins of bone trabeculae. LAP. $\times 27$.

Table Sites examined for LAP activity

\begin{tabular}{|c|c|c|c|c|c|}
\hline Sites & $\begin{array}{l}\text { Chondro- } \\
\text { cytes }\end{array}$ & $\begin{array}{l}\text { Bone } \\
\text { trabeculae }\end{array}$ & $\begin{array}{l}\text { Reaction } \\
\text { foci }\end{array}$ & $\begin{array}{l}\text { Synovial } \\
\text { fluid cells }\end{array}$ & $\begin{array}{l}\text { Synovial } \\
\text { tissue }\end{array}$ \\
\hline $\begin{array}{l}\text { Number of } \\
\text { positive cases }\end{array}$ & $12 / 15$ & $13 / 15$ & $13 / 15$ & $7 / 10$ & $15 / 15$ \\
\hline LAP intensity & +++ & +++ & +++ & +++ & +++ \\
\hline $\begin{array}{l}\overline{\text { Controls }} \\
\text { positive cases }\end{array}$ & $1 / 4$ & $2 / 4$ & $0 / 4$ & - & $1 / 4$ \\
\hline LAP intensity & + & + & - & & + \\
\hline
\end{tabular}

- No LAP activity.

+ Slight LAP activity, visible after incubation for $30 \mathrm{~min}$. ++ Barely visible LAP reaction after incubation for $15 \mathrm{~min}$. +++ Fully distinct LAP reaction after incubation for $15 \mathrm{~min}$. ++++ Very strong LAP reaction after incubation for $15 \mathrm{~min}$. 
are encountered. This enzyme may therefore be involved in the pathogenesis of the connective tissue changes caused by rheumatoid arthritis. LAP is probably a lysosomal enzyme, activated together with other lysosomal enzymes in rheumatoid arthritis. Activation of acid phosphatase and of cathepsin has previously been demonstrated in synovial tissue in rheumatoid arthritis (Barland, Novikoff, and Hamerman, 1964; Wegelius, Klockars, and Vainio, 1968; Luscombe, 1963).

Activation of LAP has also been shown in bone resorption induced by another mechanism, AT 10 overdosage (Lipp, 1959). Increased LAP activity was noted both at resorption and bone reconstruction points. This may justify the assumption that LAP is one of the mediators by which bone metabolism is regulated. LAP activation resulting in resorption of bone may similarly occur quite independently of the primary cause. This implies that activation of LAP may be a mode of response to various injurious agents characteristic of bone tissue, and that other, so far unknown, factors would determine the direction in which the reaction proceeds; that is, whether resorption or reconstruction of bone will occur. As an illustration of the synthesizing capability of LAP, its appearance in the functioning parathyroid gland may be mentioned (Pearse, 1960; Pearse and Tremblay, 1958).

The relationship of LAP to the autoimmune phenomena encountered in rheumatoid arthritis is obscure. In neoplastic tissue, LAP activity may be caused by an immune response (Glenner and others, 1959). In rheumatoid arthritis, the altered proteolytic enzyme in joints may produce protein changes which act as stimuli for autoimmunization.

According to Hollander's theory, the leucocytes of synovial fluid phagocytose rheumatoid factor. Examined by the LAP technique, the cells of synovial fluid greatly resemble 'R.A. cells' in appearance. Since, obviously, rheumatoid factor is degraded by inclusion within the cell, the idea may be entertained that LAP is one of the proteolytic enzymes employed by the cell for this purpose. It is also possible that the function of LAP may be the same when it occurs in the lining cells of synovial tissue.

LAP activity was well preserved in spite of decalcification. Since EDTA inhibits some enzymes, the tissue sections were washed in physiological saline for $15 \mathrm{~min}$. before histochemical treatment.

It must be admitted that the preservation of the the control cadavers at $+4^{\circ} \mathrm{C}$. for about 2 days may have lowered the enzymatic activity, but fresh specimens of healthy subchondral bone are exceedingly difficult to obtain for study. Amputation material does not appear to be appropriate because the bone tissue may be abnormal.

\section{Summary}

Samples of subchondral bone from fifteen, and synovial fluid from ten patients with rheumatoid arthritis were studied by a histochemical method for the presence of leucineaminopeptidase, and were compared to samples from the subchondral bone of previously healthy persons obtained at autopsy after sudden death.

The tissue samples were decalcified with versene, a treatment which did not impair leucineaminopeptidase activity. Increased activity was observed in samples from rheumatoid arthritis patients in the zone between bone and cartilage, in the cartilage cells, in the small bone cavities found inside the bone trabeculae, and in the cytoplasm of the synovial fluid cells which closely resembled 'R.A. cells'.

The significance of leucineaminopeptidase activity in the pathogenesis of rheumatoid arthritis remains a matter for speculation, and the possible association between this enzyme and autoimmunization is discussed.

I wish to thank Prof. S. Talanti, M.D., for helpful advice and criticism, Dr. K. Vainio, M.D., Heinola, for his courtesy in supplying the pathological samples, and Prof. U. Uotila, M.D., for the control samples.

This work was supported by a grant from the Finnish Rheumatism Association.

\section{References}

ALI, S. Y. (1964) Biochem. J., 93, 611 (The degradation of cartilage matrix by an intracellular protease).

BALOGH, K., JR. (1962) J. Histochem. Cytochem., 10, 232 (Decalcification with versene for histochemical study of oxidative enzyme systems).

- (1963) J. dent. Res., 42, 1457 (Histochemical study of oxidative enzyme systems in teeth and peridental tissues).

Barland, P., Novikoff, A. B., and Hamerman, D. (1964) Amer. J. Path., 44, 853 (Fine structure and cytochemistry of the rheumatoid synovial membrane, with special reference to lysosomes).

Burstone, M. A. (1956) J. nat. Canc. Inst., 16, 1149 (Histochemical demonstration of proteolytic activity in human neoplasm).

- (1962) 'Enzyme Histochemistry and Its Application in the Study of Neoplasms', p. 409. Academic Press, New York and London.

GlenNer, G. C., Burstone, M. S., AND Meyer, D. B. (1959) J. nat. Canc. Inst., 23, 857 (A study of amonipeptidase activity in the stroma of neoplastic tissue, with a comparison of histochemical techniques).

Hollander, J. L., MCCarty, D. J., Astorga, G., and Castro-Murillo, E. (1965) Ann. intern. Med., 62, 271 (Studies on the pathogenesis of rheumatoid joint inflammation. I. The 'R.A. cell' and a working hypothesis). 
Hütrt, S., AND Marcović, O. (1963) Bratisl. lek. Listy, 43, 585 (Aminotripeptidase activity of the synovial effusion).

LeVer, J. D., AND Ford, E. H. R. (1958) Anat. Rec., 132, 525 (Histological, histochemical and electron microscopic observations on synovial membrane).

LipP, W. (1959) J. Histochem. Cytochem., 7, 205 (Aminopeptidase in bone cells).

Luscombe, M. (1963) Nature (Lond.), 197, 1010 (Acid phosphatase and catheptic activity in rheumatoid synovial tissue).

Nachlas, M. M., Crawford, D. T., and Seligman, A. M. (1957) J. Histochem. Cytochem., 5, 264 (The histochemical demonstration of leucine aminopeptidase).

Pearse, A. G. E. (1960) 'Histochemistry, Theoretical and Applied,' 2nd ed., pp. 587-600. Churchill, London.

- AND TRemblay, G. (1958) Nature (Lond.), 181, 1532 (Leucine aminopeptidase in rat parathyroid and its relation to parathyroid hormone production).

Rawson, A. J., Abelson, N. M., AND Hollander, J. L. (1965) Ann. intern. Med., 62, 281 (Studies on the pathogenesis of rheumatoid joint inflammation. II. Intracytoplasmic particulate complexes in rheumatoid synovial fluids).

Restifo, R. A., Lussier, A. J., Rawson, A. J., Rockey, J. H., AND Hollander, J. L. (1965) Ibid., 62, 285 (Studies on the pathogenesis of rheumatoid joint inflammation. III. The experimental production of arthritis by the intra-articular injection of purified 7S gamma globulin).

Ropes, M. W., Bennett, G. A., CobB, S., JACox, R., and Jessar, R. A. (1959) Ann. rheum. Dis., 18, 49 (1958 Revision. Diagnostic criteria for rheumatoid arthritis).

Smith, C., and Hamerman, D. (1962) Arthr. and Rheum., 5, 411 (Acid phosphatase in human synovial fluid).

VAINIO, U. (1966) Ann. rheum. Dis., 25, 253 (A histochemical study on leucinoaminopeptidase activity in the synovial membrane of patients with rheumatoid arthritis).

Wegelius, O., Klockars, M., and Vainio, K. (1968) Acta. med. scand., 183, 549 (Acid phosphatase activity in rheumatoid synovia).

Weissmann, G., AND SPILBerg, I. (1968) Arthr. and Rheum., 11, 162 (Breakdown of cartilage proteinpolysaccharide by lysosomes).

- AND Thomas, L. (1963) J. clin. Invest., 42, 661 (Studies on lysosomes. II. The effect of cortisone on the release of acid hydrolases from a large granulae fraction of rabbit liver induced by an excess of vitamin A).

Ziff, M., Simson, J., Scull, E., Smith, A., Shatton, J., And Mainland, D. (1955) Ibid., 34, 27 (Aminotripeptidase content of synovial fluid in arthritic diseases).

- Gribetz, H. J., AND Lospalluto, J. (1960) Ibid., 39, 405 (Effect of leukocyte and synovial membrane extracts on cartilage mucoprotein). 